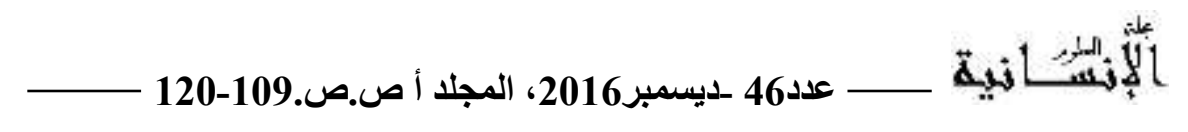

\title{
النظام القانوني لعقد الإمتياز في إطار الإستثمار
}

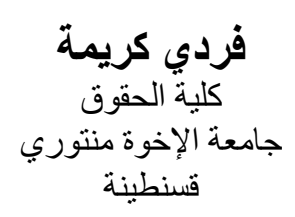

إن إنتقال البنية الاقتصادية لدول

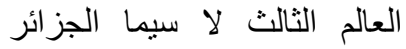

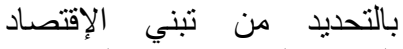
الموجه إلى الإقتصاد الحر لابد لإبد

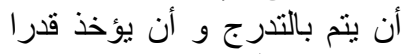

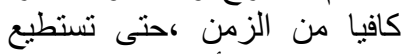

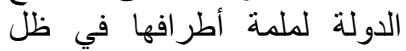

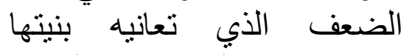
الإقتصادية على وجه الإن تعانه التحديد فبدلا من الإنتقال من نقيض إلى إلى لئل

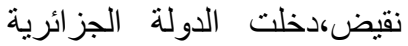
في مرحلة إصلاحات شاملة الجاتلة

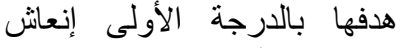

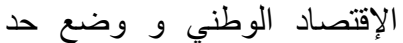
لإِختلالات الداخلية و الخارجية فيه ،ضف إلى ذلك وضع الإطار

$$
\begin{aligned}
& \text { تنظلب سياسة تطوير و تشجيع الإستثمار في الجزائر أن تكون }
\end{aligned}
$$

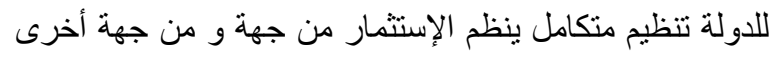

$$
\begin{aligned}
& \text { تنظيم إستغلال العقار الذي يتحكم إلى حد بعيد في تحقيق و الإنسئ }
\end{aligned}
$$

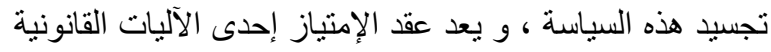

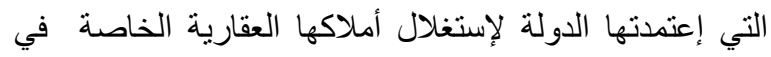

$$
\begin{aligned}
& \text { إطار تحقيق مشاريع إستثمارية و إنجاح هذه السياسة من خلال }
\end{aligned}
$$

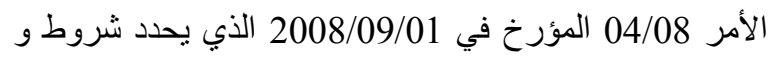

$$
\begin{aligned}
& \text { كيفيات منح الإمنياز على الأراضي التابعة للأملاك الخاصة }
\end{aligned}
$$

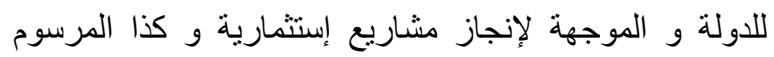

$$
\begin{aligned}
& \text { التنفيذي المصاحب له 152/09 }
\end{aligned}
$$

\section{Abstract :}

The policy of development and encouragement of investment in Algeria needs a full state organization that organizes investment on one part; and organizes the exploitation of property that essentially controls the application of this politic on the other part.

The concession contract is one of the legal mechanisms chosen by the state to exploit lands within its private domain; in the framework of realization of investment projects and to ensure the success of this politic through ordinance $08 / 04$ dated on September 01 ${ }^{\text {st. }} ; 2008$ establishing the conditions and methods of land concession within state private domain; aimed at the realization of investment projects with the executive decree 09/152 that comes with it. 
التثريعي وتنبي سياسات مندرجة تستطيع من خلالها التحضير لتغيير النمط الاقتصادي دون نقلات

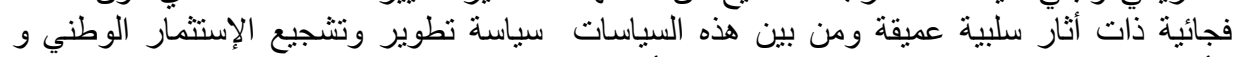

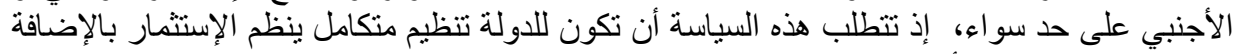

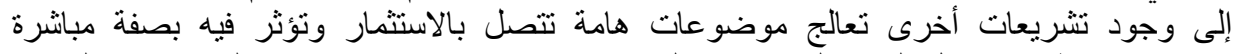

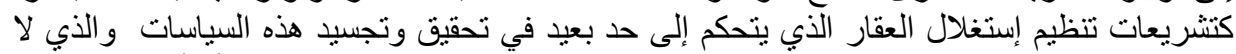

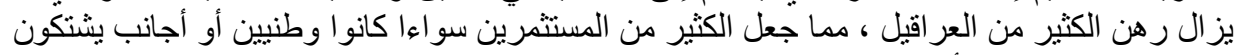

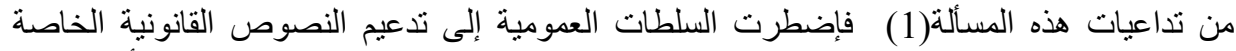

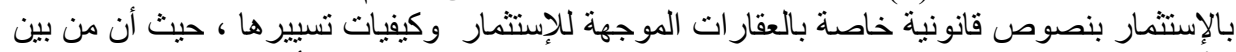

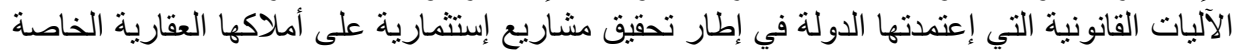

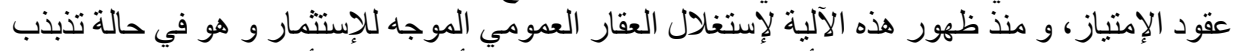

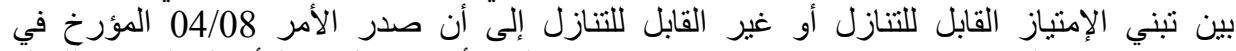

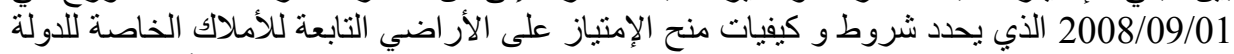

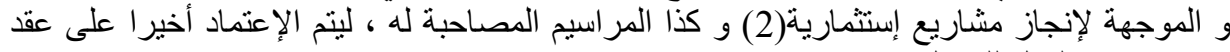

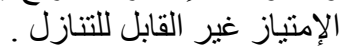

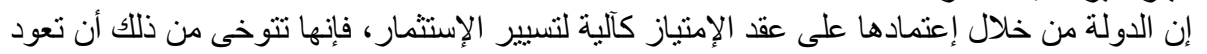

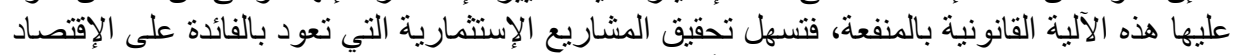

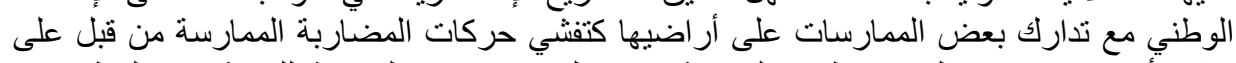

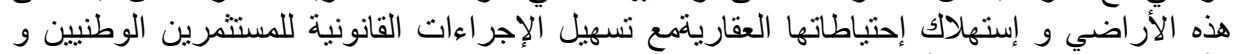

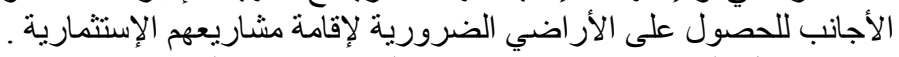

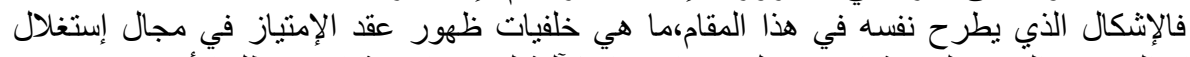

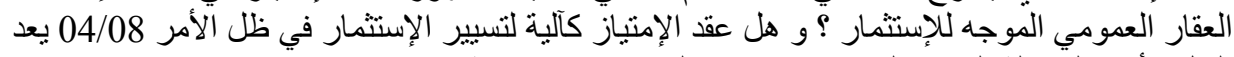

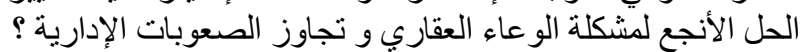

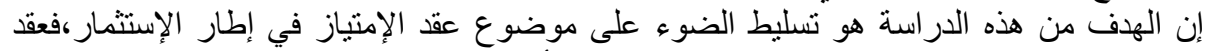

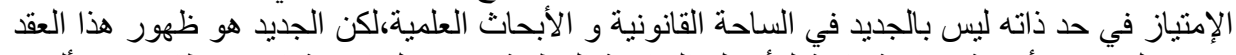

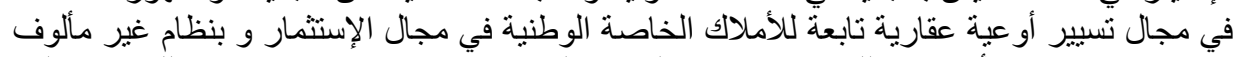

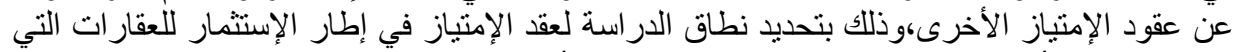

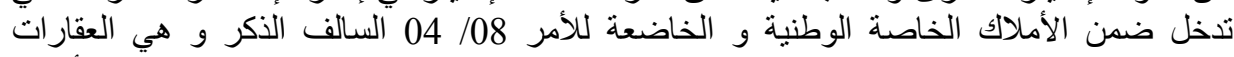

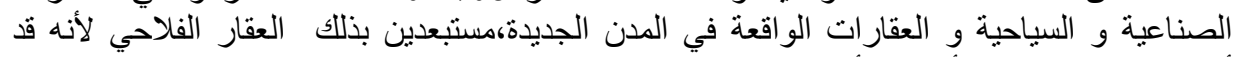

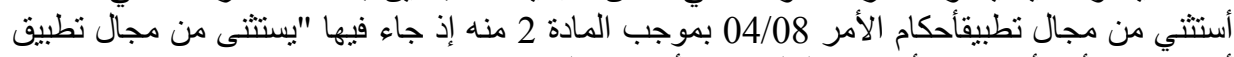

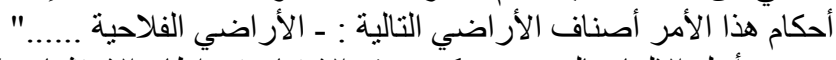

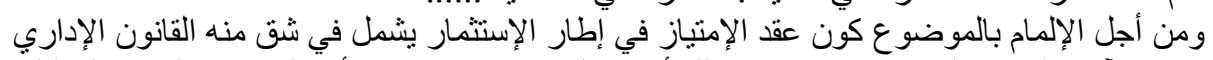

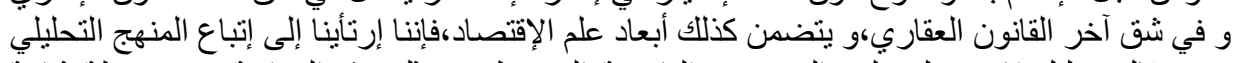

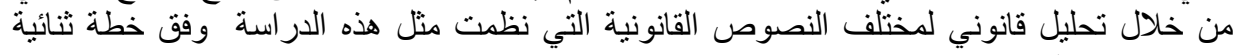

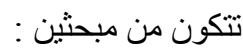
نتناول في المبحث الأول ماهية عقد الإمتياز في إطار الإستثمار،من خلال تعريفه و معرفة طبيعته القانونية و كذا بيان الأركان التي يقوم عليها.

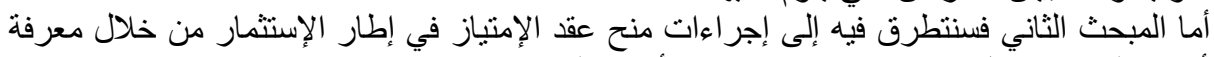

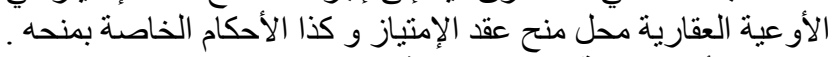

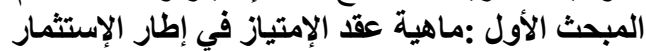

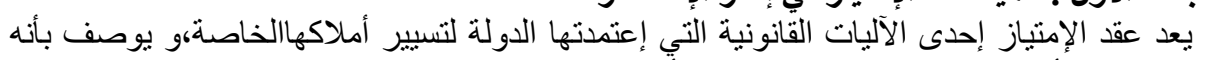

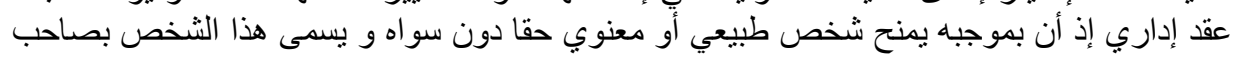

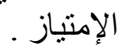


المطلب الأول :تعريف عقد الإمتياز و طبيعته القانونية

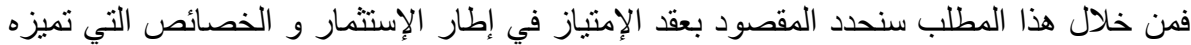

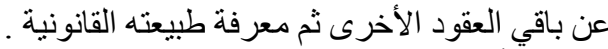

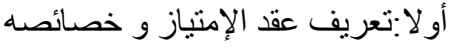

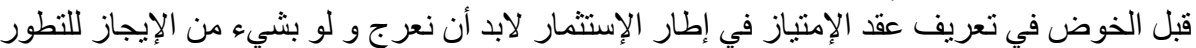

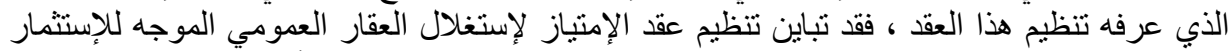

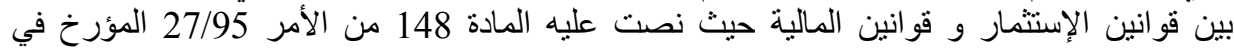

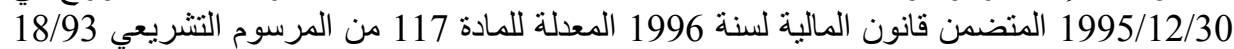

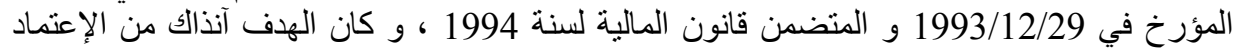

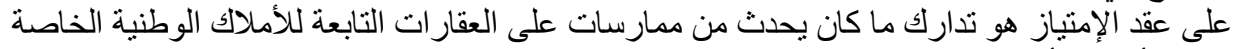

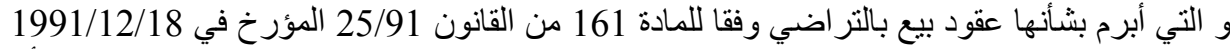

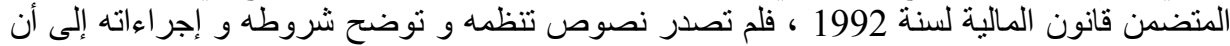

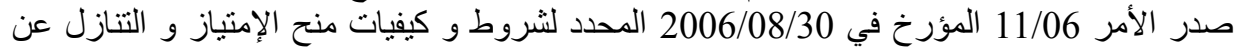

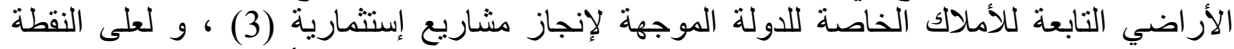

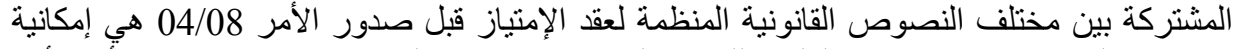

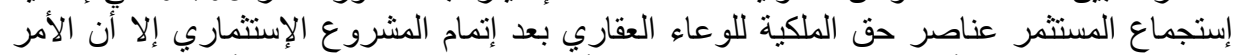

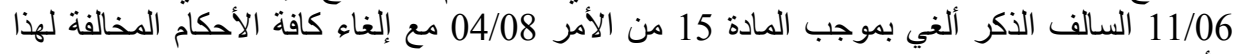

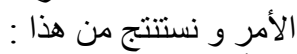

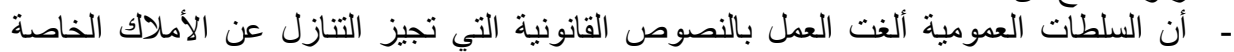

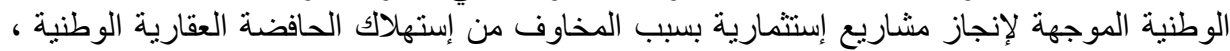

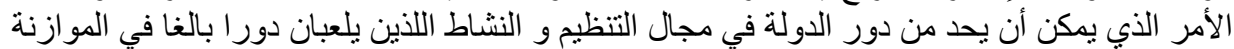

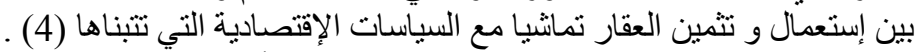

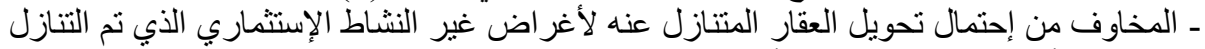

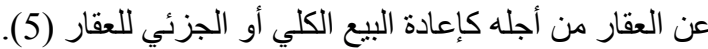

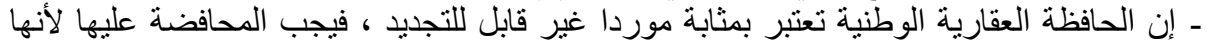

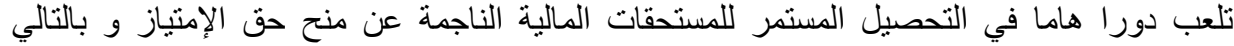

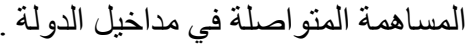
- إستحو اذ بعض المؤسسات العمومية على مساحات شاسعة في حين أن حاجتها الفعلية لا تتعدى

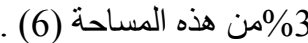
ـ تعرض بعض المناطق الصناعية عبر الوطن إلى تدهور في التهيئة و التسيير مما جعلها تتحرف عن

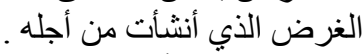

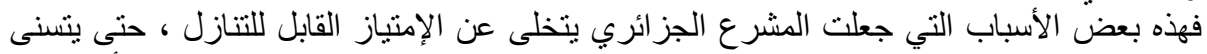

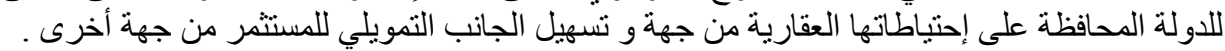

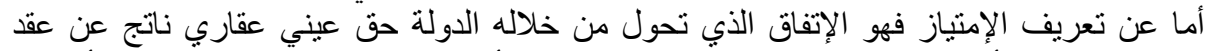

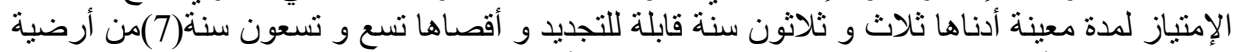

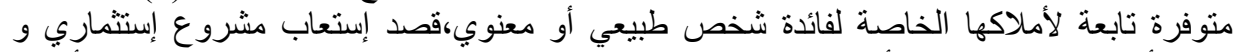

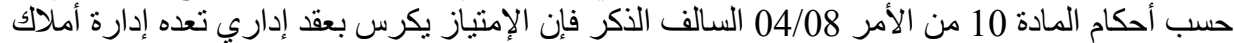

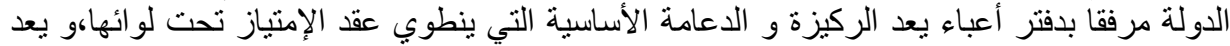

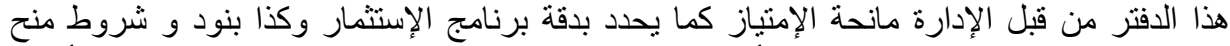

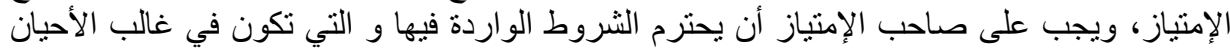


كما يجب أن يتضمن عقد الإمنياز تحت طائلة البطلان شروط منع التنازل أو الإيجار من الباطن

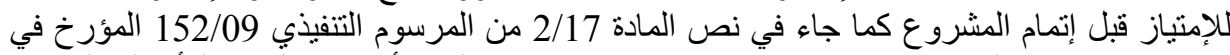

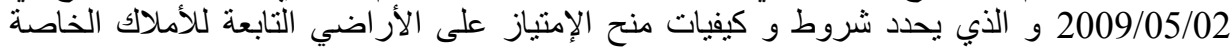

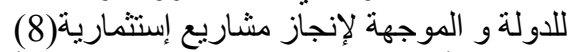

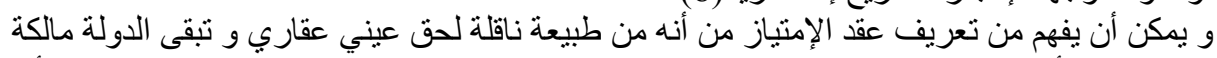

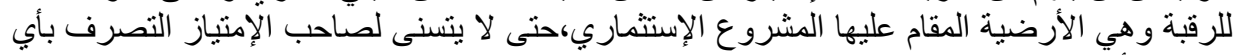

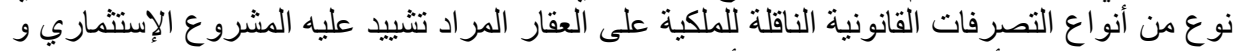

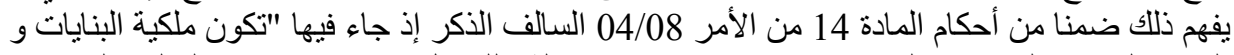

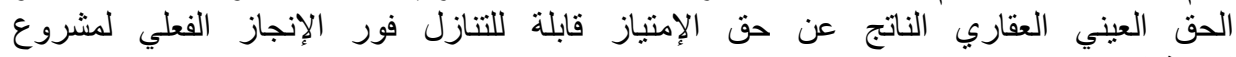

من تعريف عقد الإمنياز فإننا نستتتج مجمو عة من الخصائص التي يتمتع بها هذا العقد من بينها:

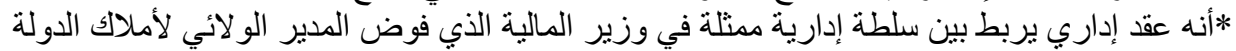

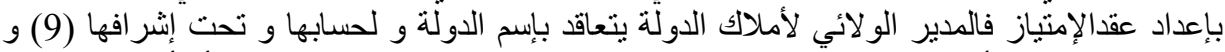

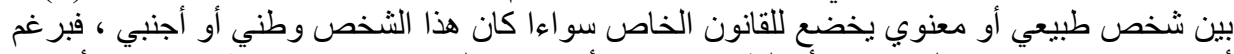

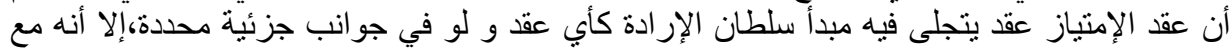

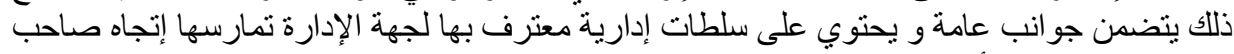

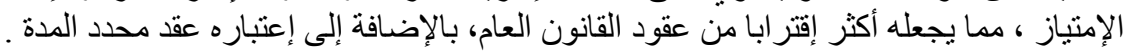

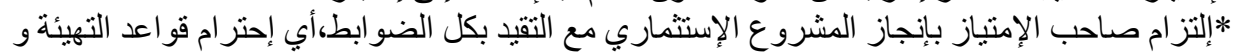

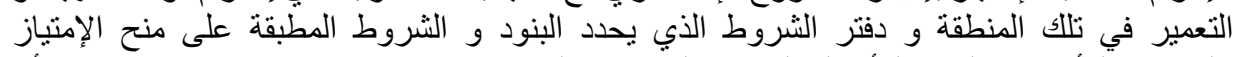

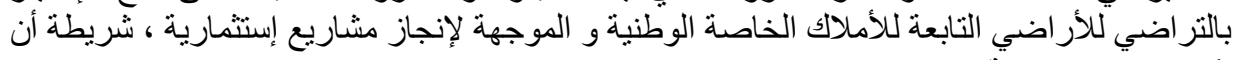
تكون غير مخصصنة.

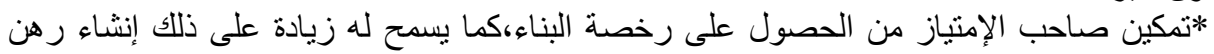

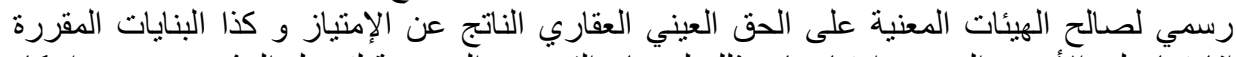

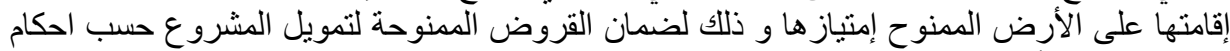

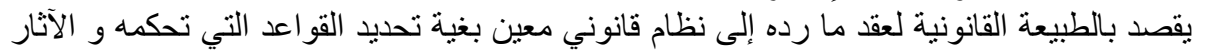

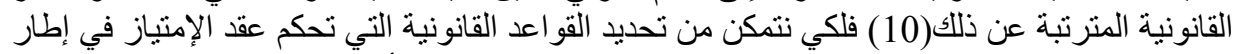

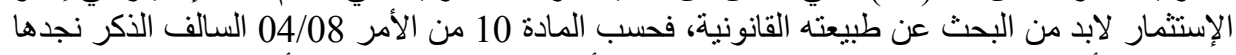

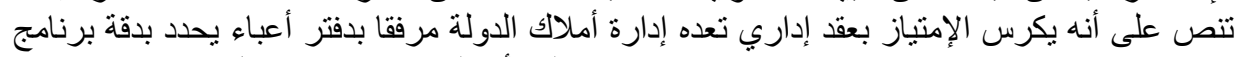

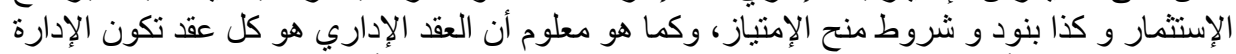

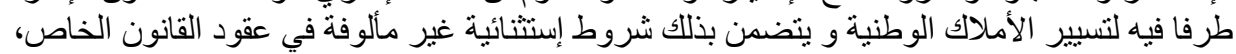

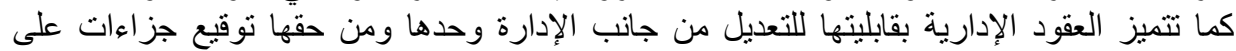

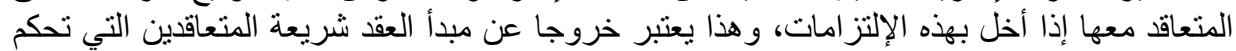

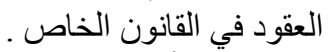

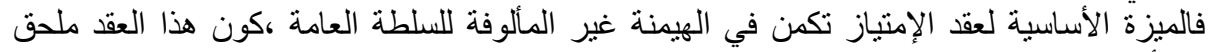

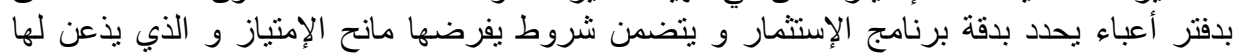

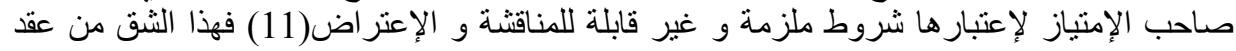

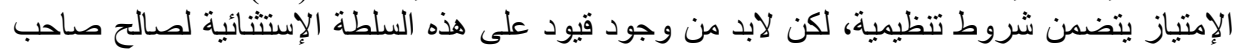

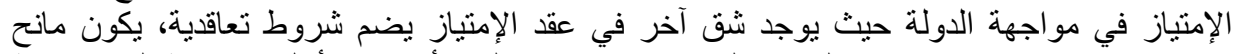

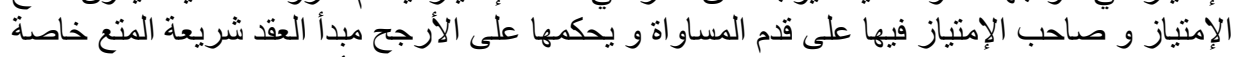

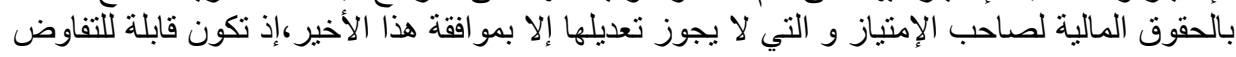




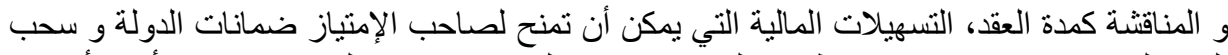

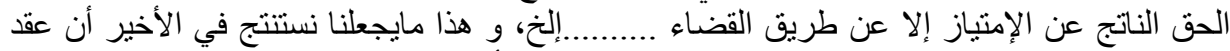

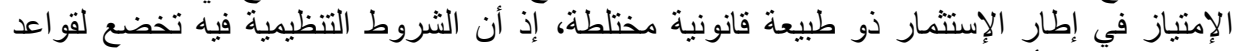

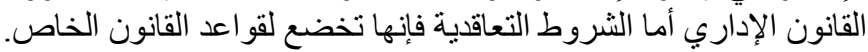

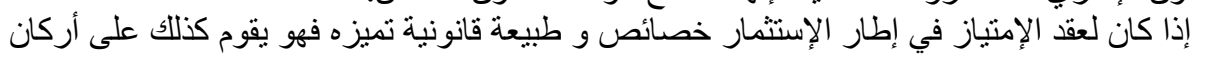

المطلب الثاني:أركان عقد الإمنياز

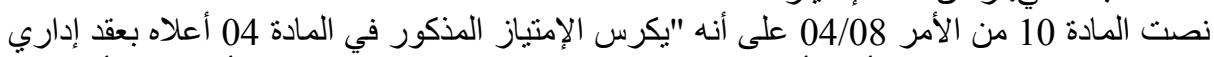

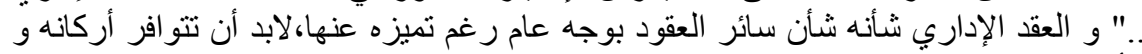

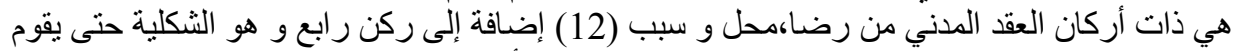

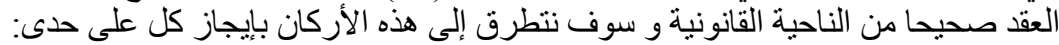

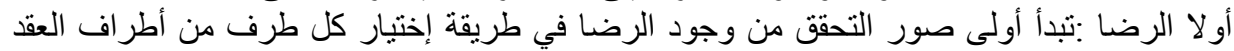

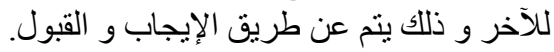

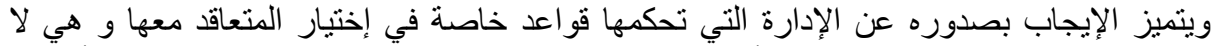

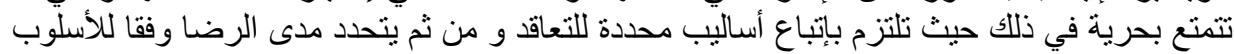

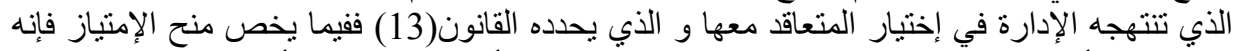

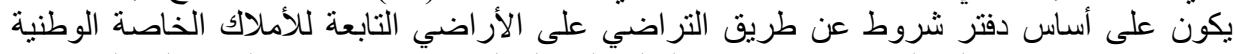

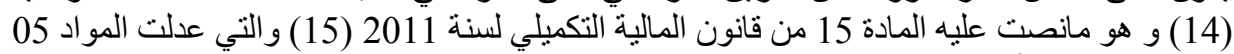

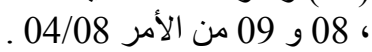

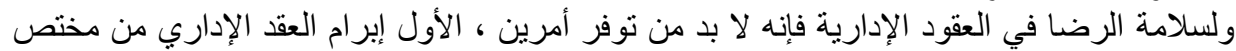

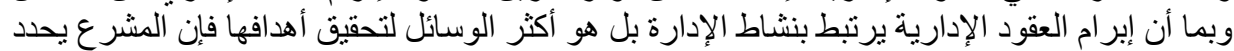

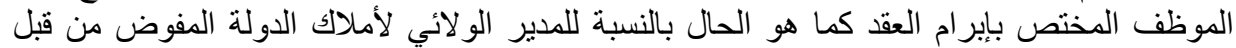

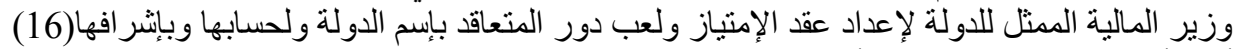

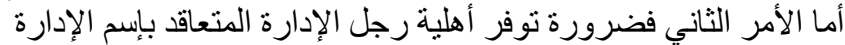

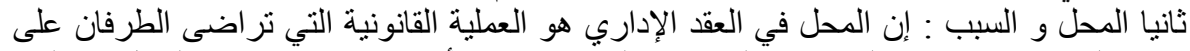

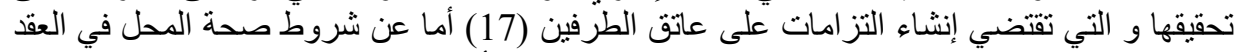

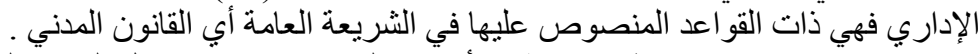

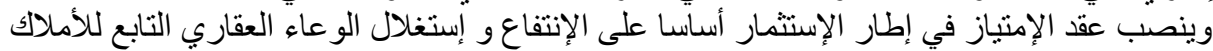

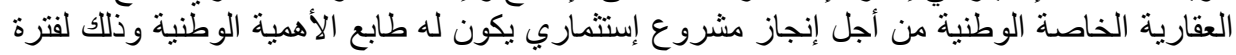
معينة من الزمن (18) منارئة أما عن السبب فيكاد يجمع الفقه الإداري على أن القو اعد التي تحكم السبب في العقد الإداري هي ذاتها

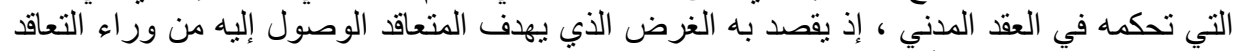

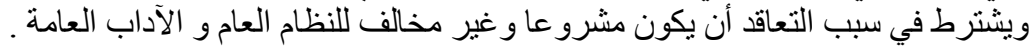

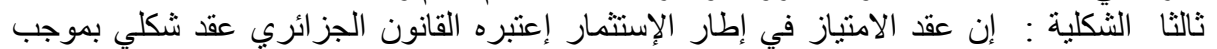

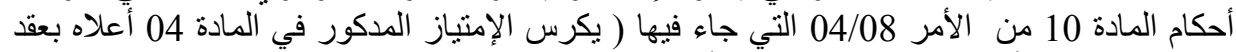

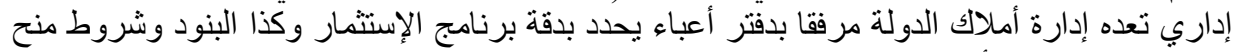

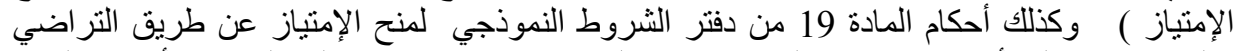
و التي نصت على أنه ( ينت إعداد العقد الإداري المنضئن المن منح الإمتياز على القطعة الأرضية لفائدة

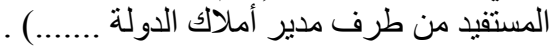

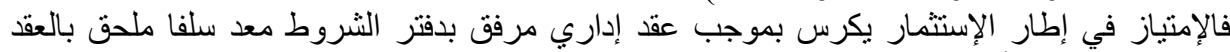
ولهذا يمكن القول بأن عقد الإمتياز في إطار الاستثمار هو عقد ذو طبيعة قانونية مختلطة ، مركز تعاقدي بالئي 
تطبق عليه أحكام القانون الخاص كالقانون الددني ومركز لائحي تطبق عليه أحكام القانون العام كالقانون

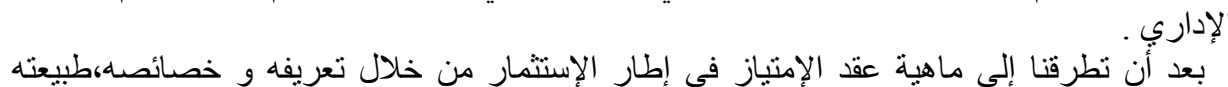

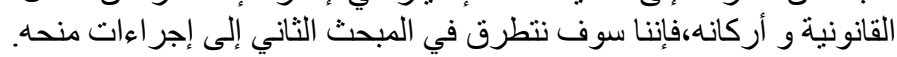

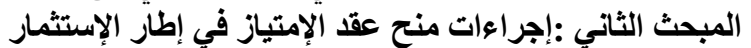

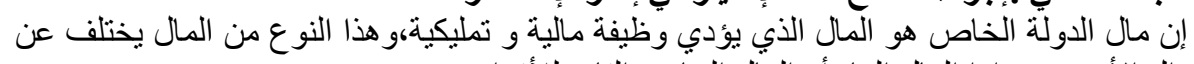

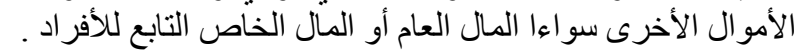

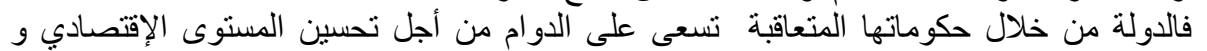

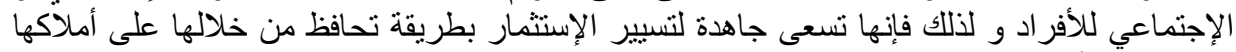

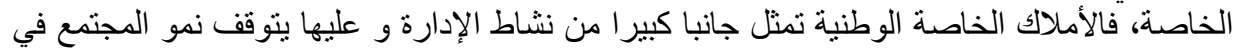

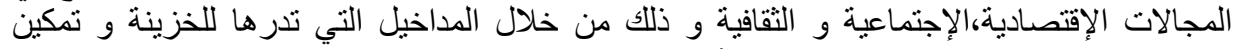

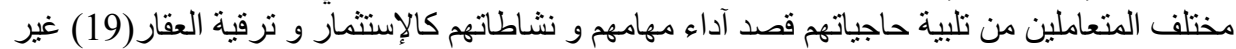

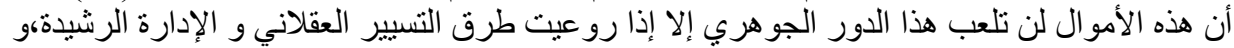

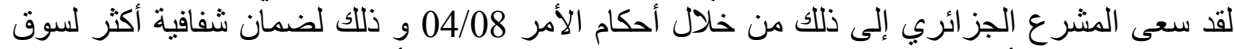

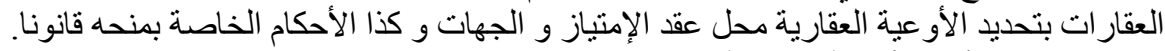
المطلب الأول:الأوعية العقارية محل منح عقد الإنتية الإنياز

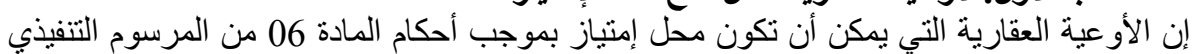

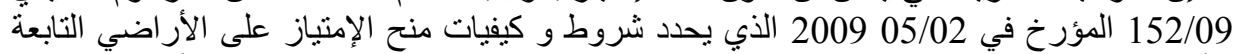

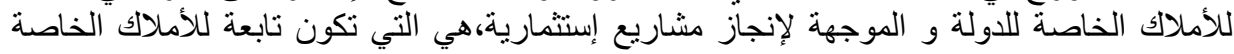

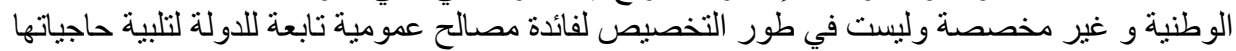

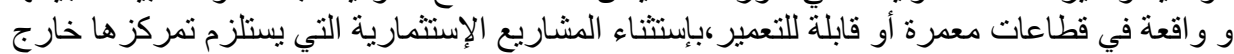

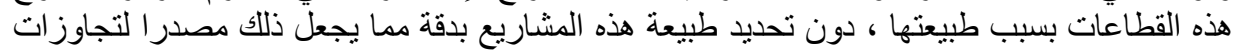

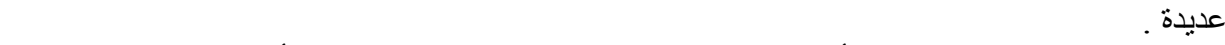

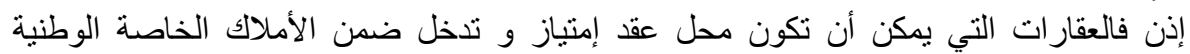

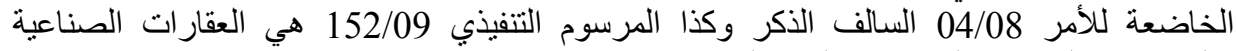

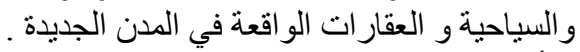

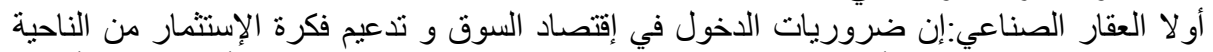

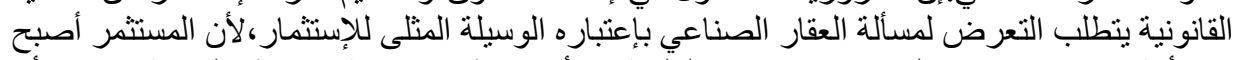

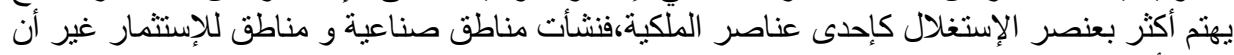

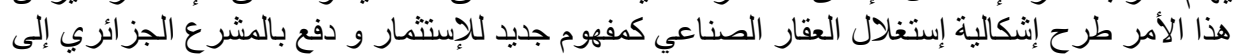

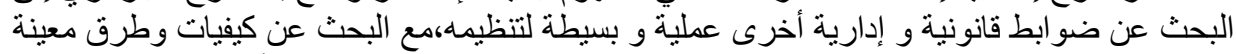

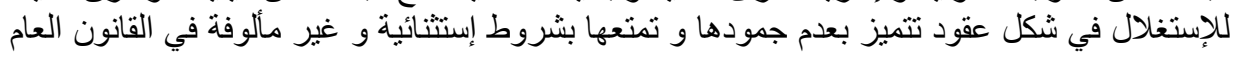

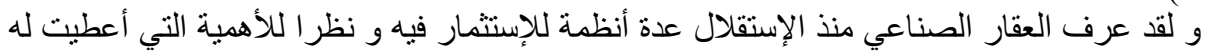

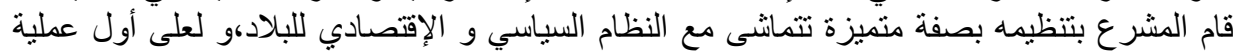

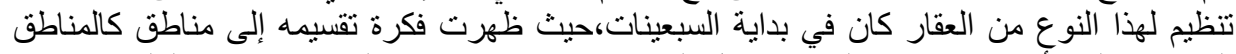

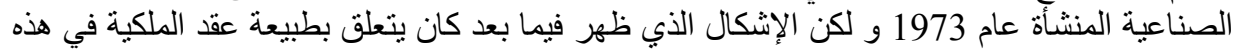

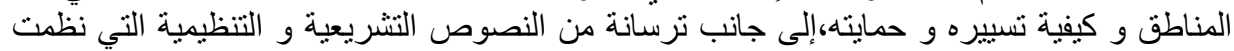

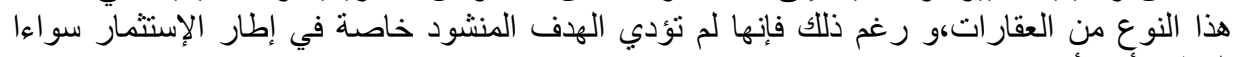

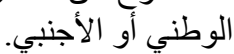

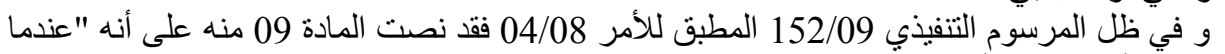

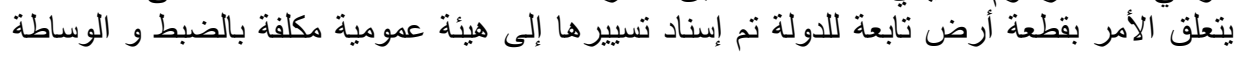




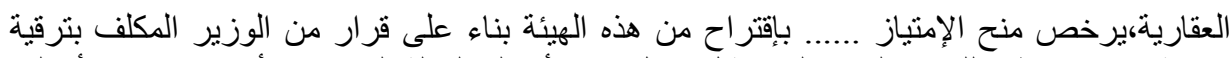

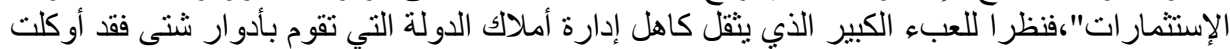

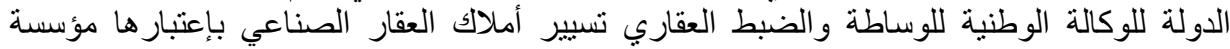

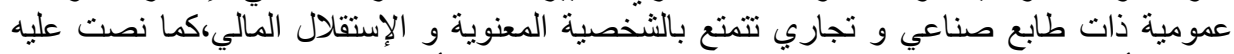

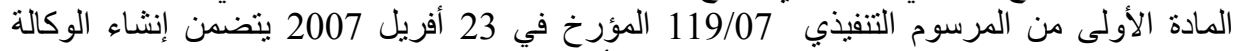

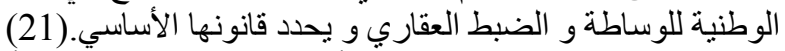

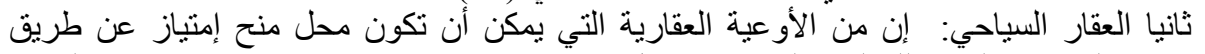

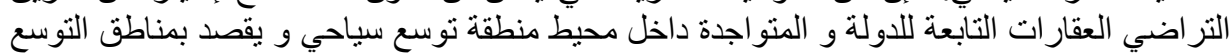

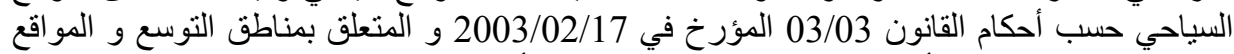

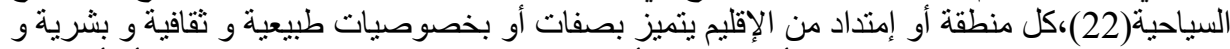

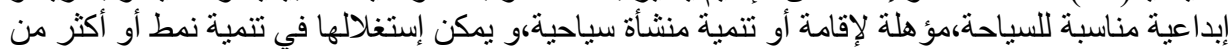
السياحة ذات مردودية.

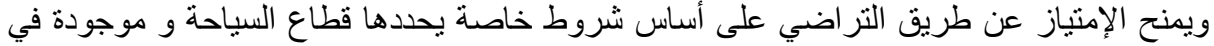

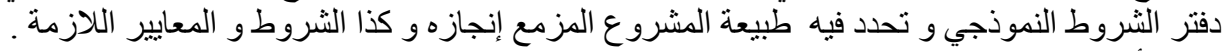

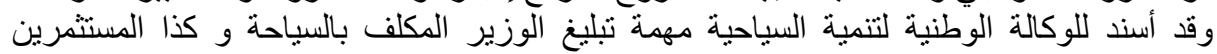

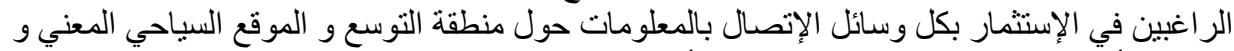

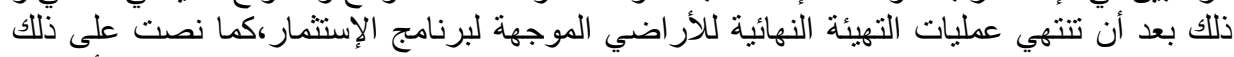

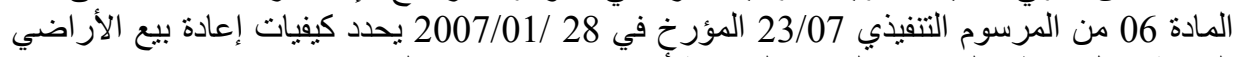

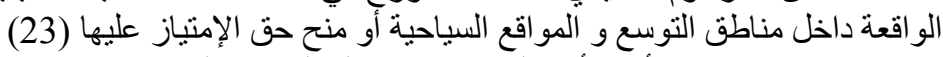

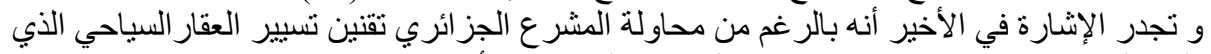

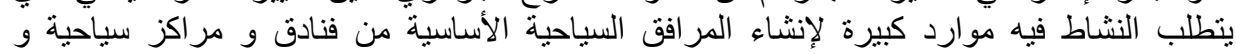

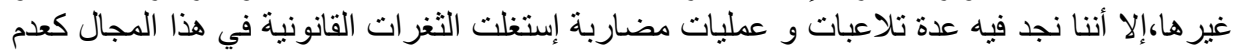

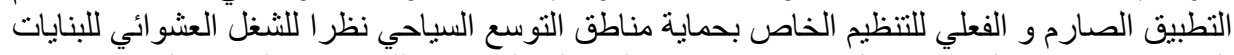

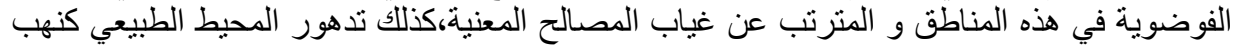

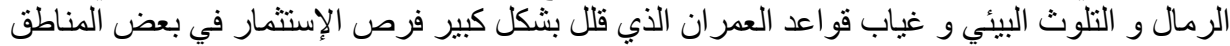

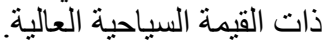

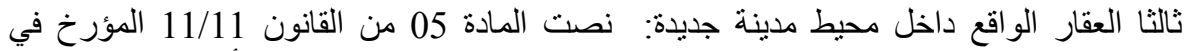

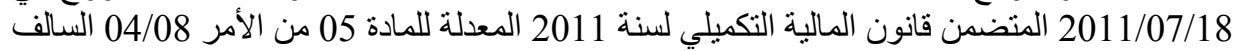

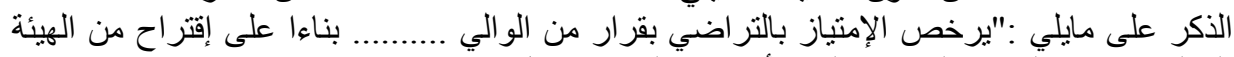

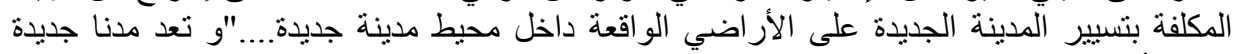

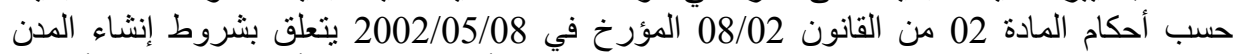

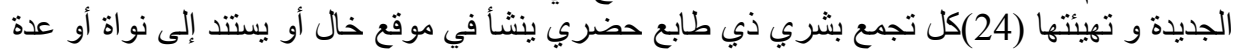

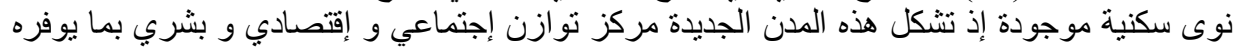

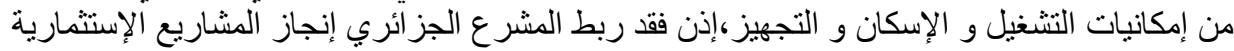

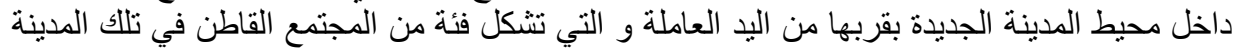

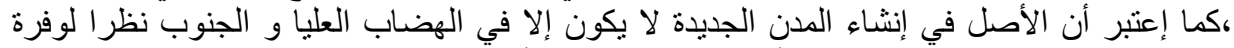

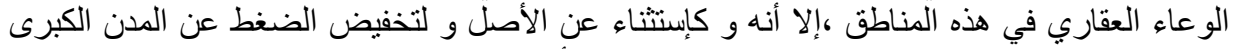

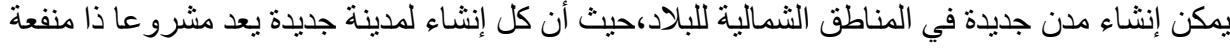
وطنية.

أما فيما يخص العقار ات داخل محيط الددن الجديدة فإن الدولة تتولى تكوين كل أو جزء من من الحافظة

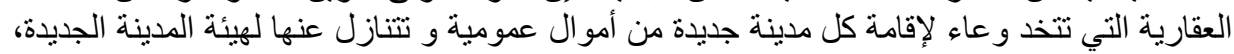

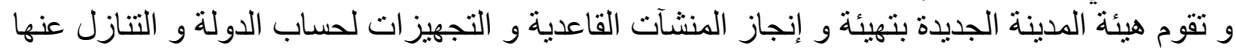


بالبيع للمستعطلين الآخرين وفقا للتشريع المعمول به، هذه الهيئة التي نصت عليها المادة 07 من القانون

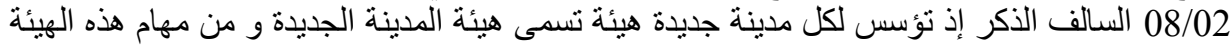
القيام بالأعمال العقارية و جميع عمليات التنسيق و التسيير و الترقية التجارية الضرورية لإنجازية النية الدينة الجديدة.

و تجدر الإثارة في الأخير أن المشرع ضمن أحكام الأمر 04/08 قد إستثنى بعض العقار العات التات التابعة

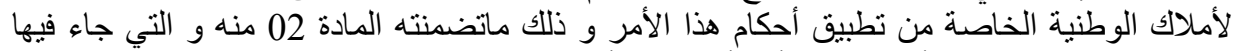

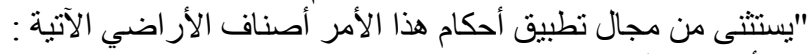
الأر اضيى الفلاحية الإلية

القطع الآرضية المتو اجدة داخل مساحات منجمية الفارية

القطع الارضية المتواجدة داخل مساحات البحث عن المحربة الدروقات و إستغلالها و مساحات حماية

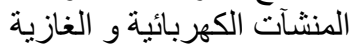

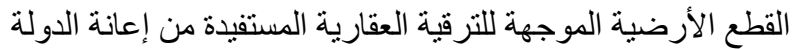

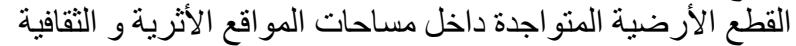

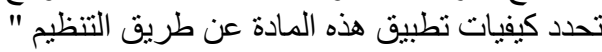

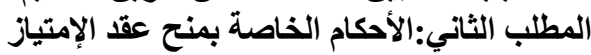

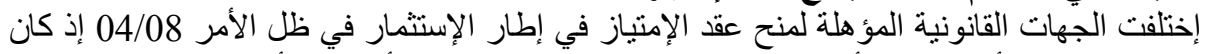

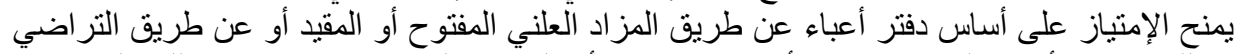

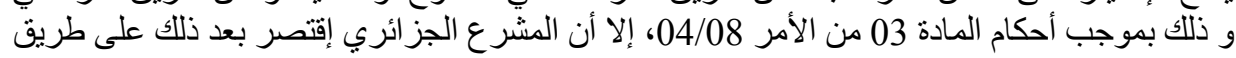

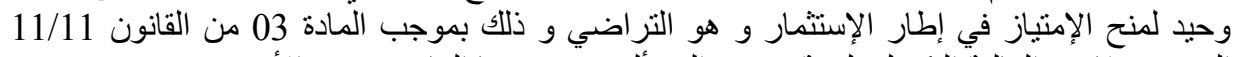

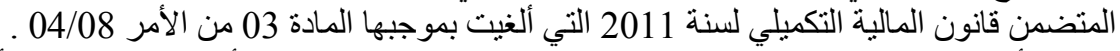

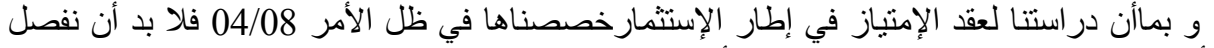

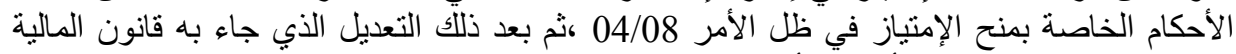

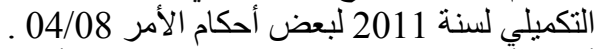

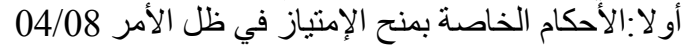

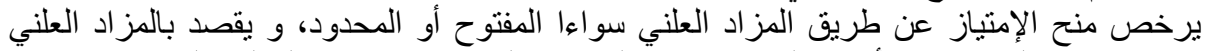

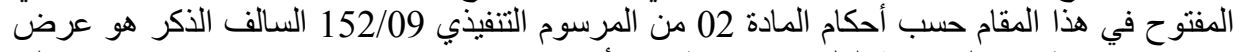

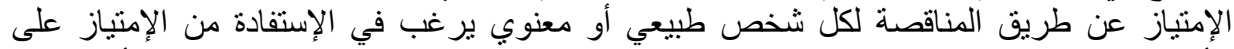

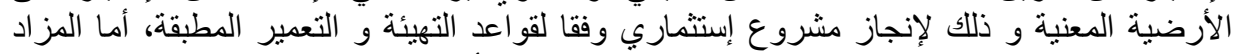

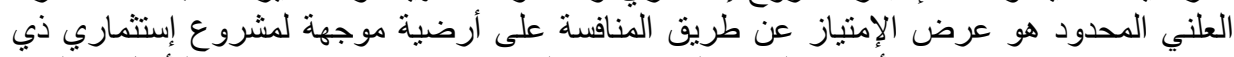

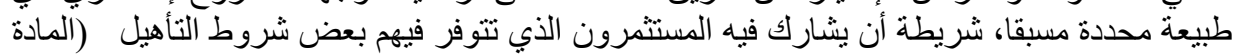

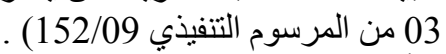

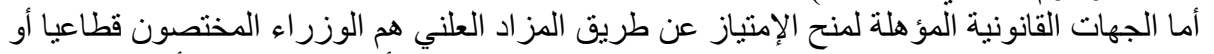

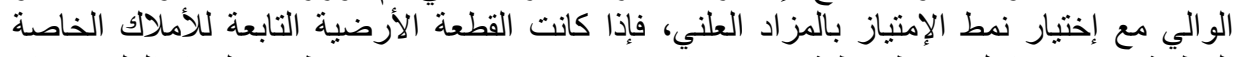

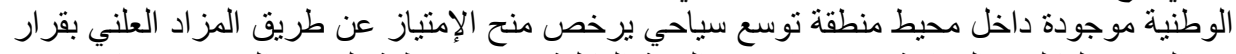

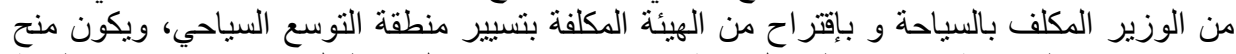

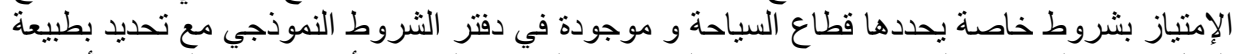

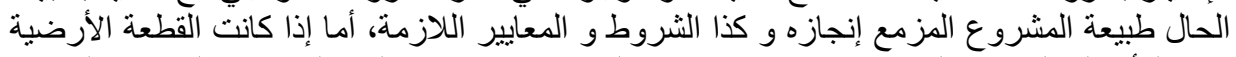

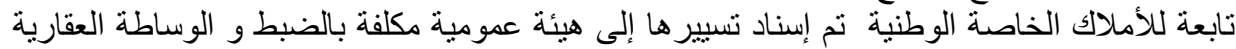

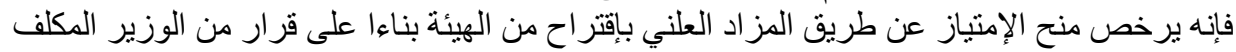

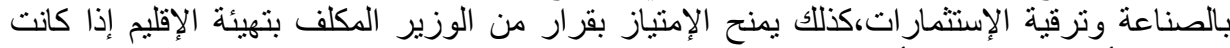

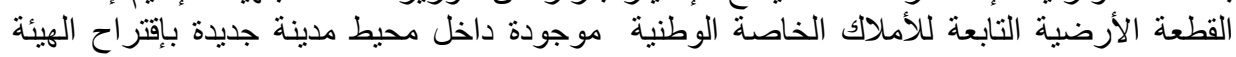




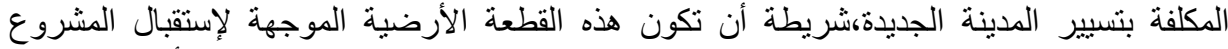

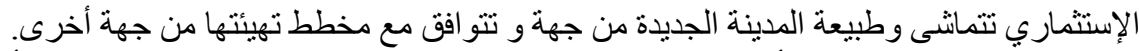

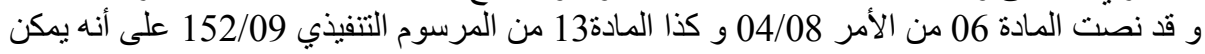

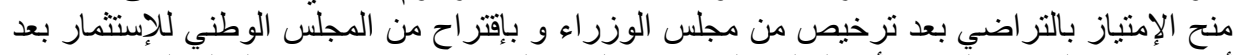

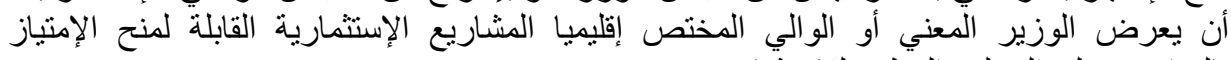
بالتر اضي على المجلس الوطني للإِنتثمار.

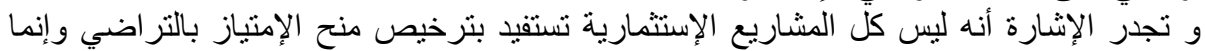

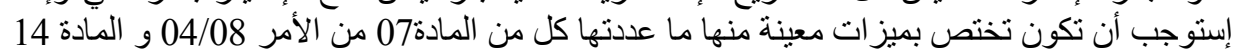

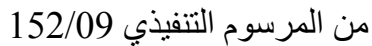

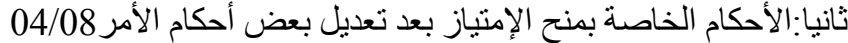

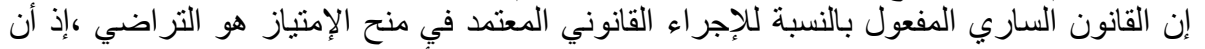

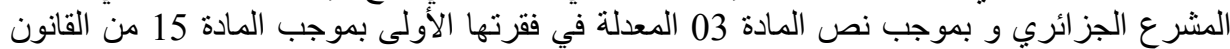

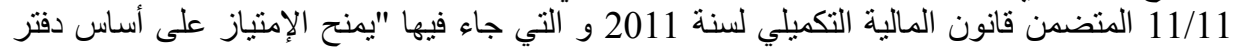

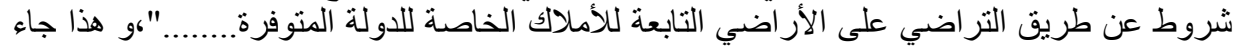

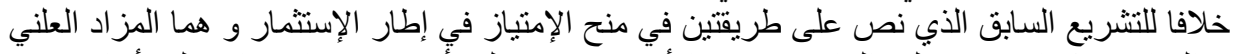

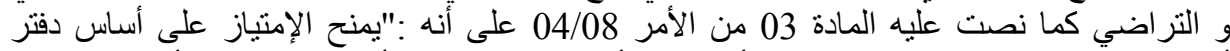

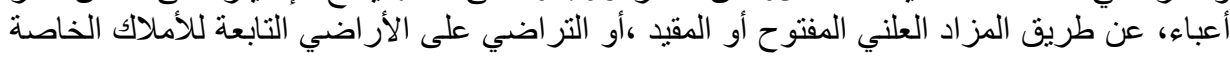

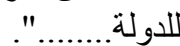

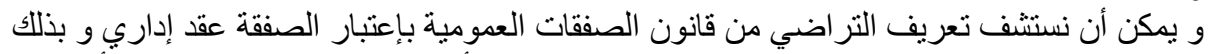

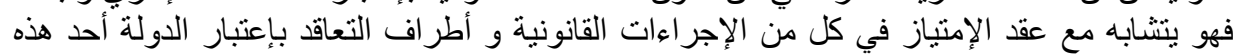

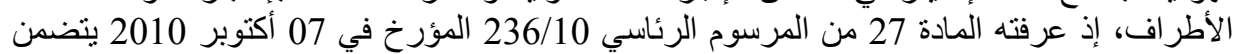

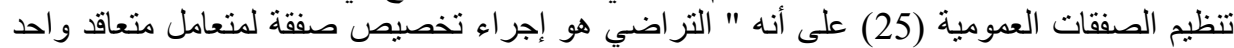

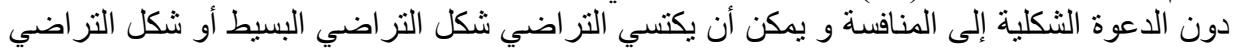

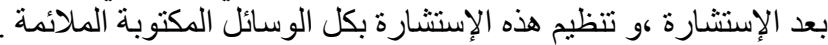

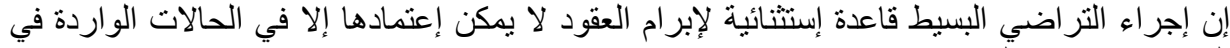

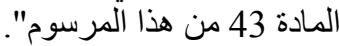

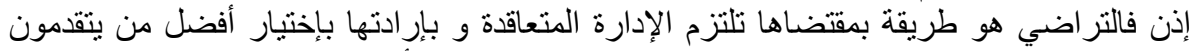

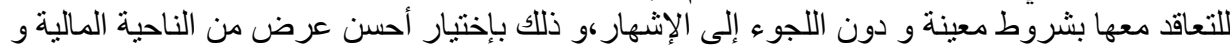

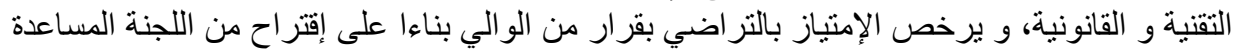

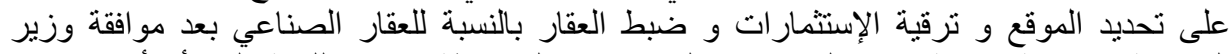

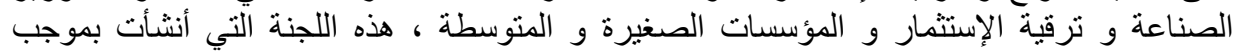

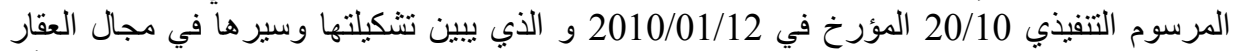

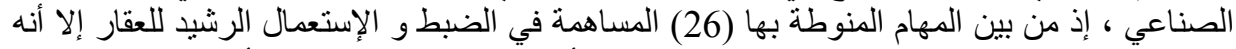

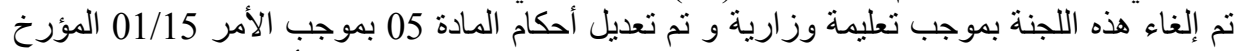

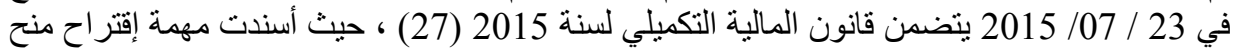

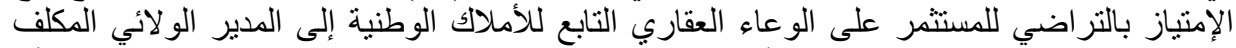

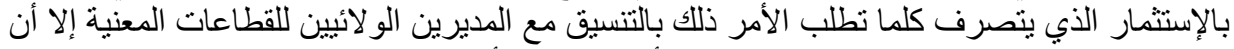

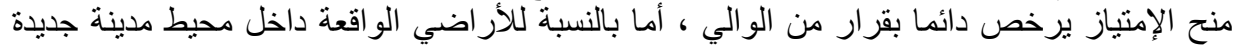

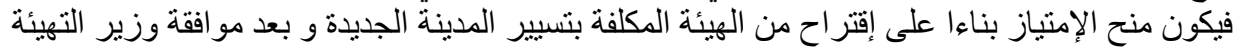

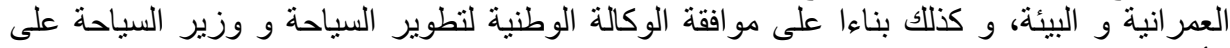
الأراضي التابعة لمنطقة التوسع السياحي. 


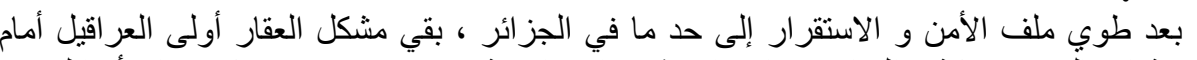

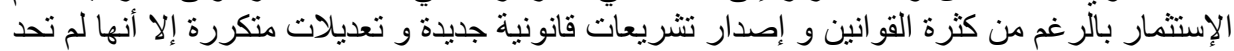

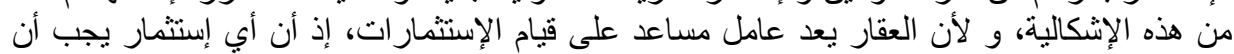

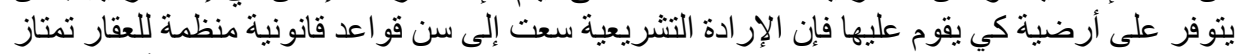

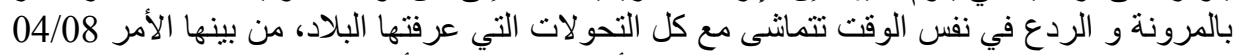

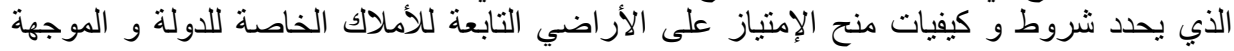

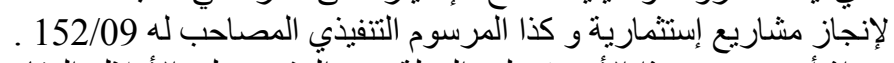

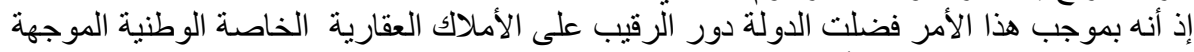

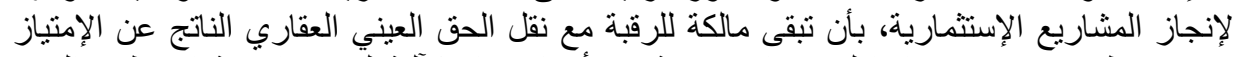

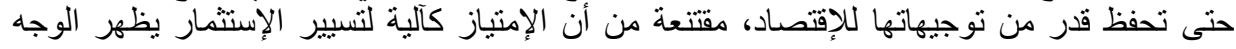

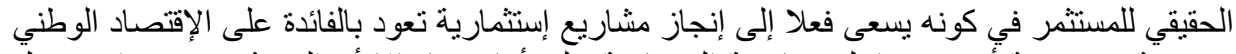

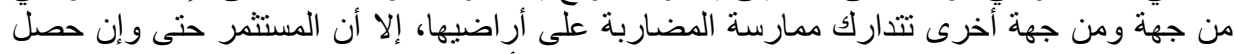

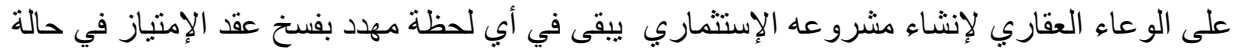

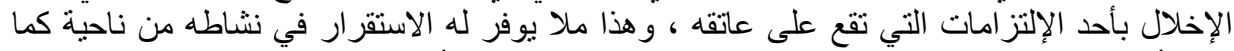

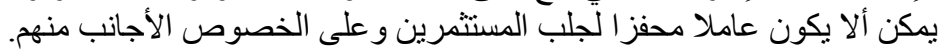

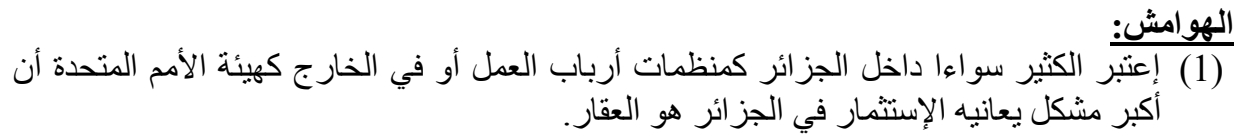

Examen de la politique de l'investissement ALGERIE, conférence des nations unie sur le commerce et le développement, page 55.

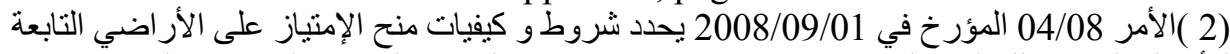
للأملاك الخاصة للاولة و الموجهة في لإنجاز مشاريع إستثمارية، الجريدة الرسمية العدد 49 ،المؤرخة في الإخي .2008/09/03

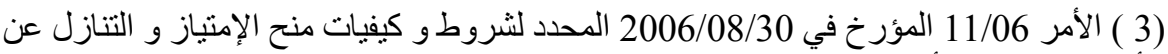

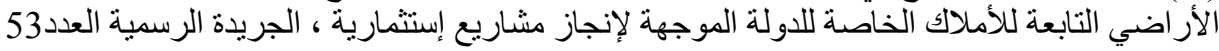

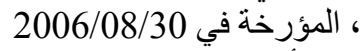

(4 ) أسماء منصور ، عقد الإمتياز كوسيلة لإستغلال العقار الصناعي، رسالة ماجستير ، كلية الحقوق،

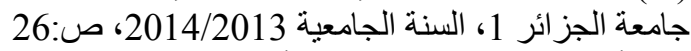
(5 ) أعمر يحياوي، الوجيز في الأمو ال الخاصة التابعة للاولة و والجمائلة الجاعات المحلية، دار هومه، طبعة

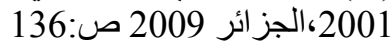

(6)مر اد بلكعيبات، منح الإمتياز للإستثمار الصناعي في التشريع الجز ائري، أطروحة مقدمة لنيل

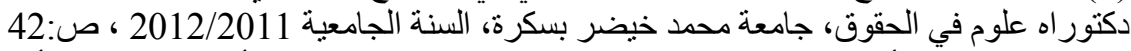

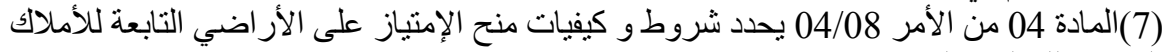
الخاصة للاولة و الموجهة لإنجاز مشاريع إستثمارية الإنية

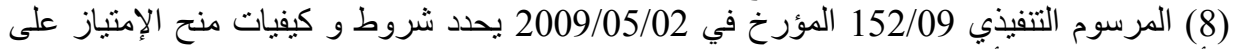

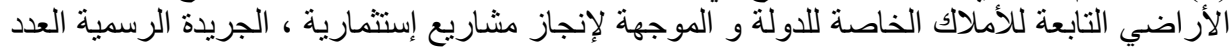

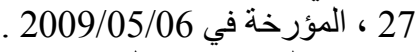

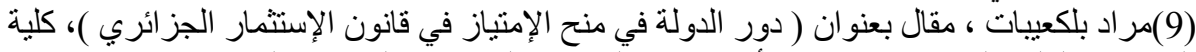

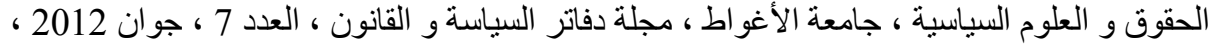


31 : 31 (10)

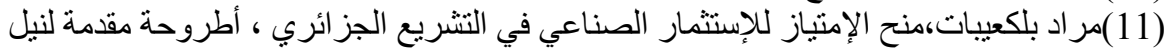

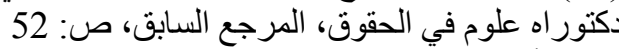

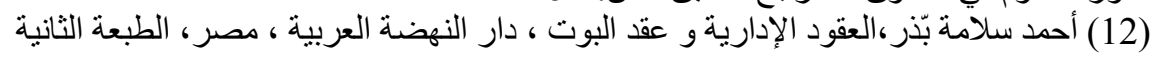

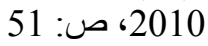

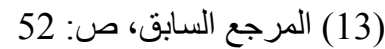

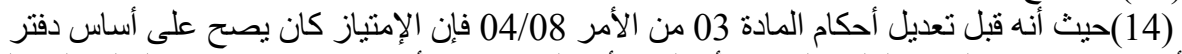

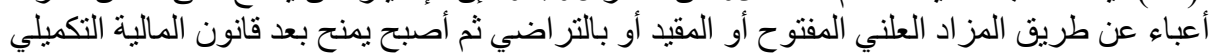
2011 فقط بالتر اضي.

(15) القانون 11/11 المؤرخ في 2011/07/18 يتضمن قانون المالية التكميلي لسنة $2011 / 0720$ ، الجريدة

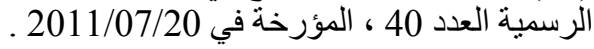

(16) مر اد بلكعيبات ، مقال بعنوان (دور الدولة في منح الإمتياز في قانون الإستثمار الجزائري ) ،

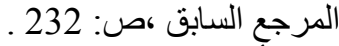

(17) أحمد سلامة بذر ، المرجع السابق ، ص: 54

(18) manuel de droit domanial, ministère des finance, direction générale du domaine nationale, septembre 2007, page 64 .

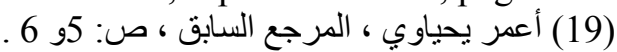

(20) منتديات الحقوق و العلوم القانونية ، العقار الصناعي في الجزائر ، الموقع الإلكتروني :

www.droit. Dz.com.

(21) المرسوم التنفيذي 119/07 المؤرخ في 2007/04/23 ينضمن إنشاء الوكالة الوطنية للوساطة و

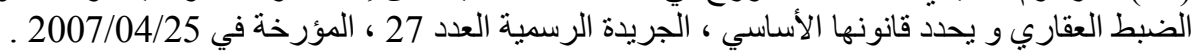

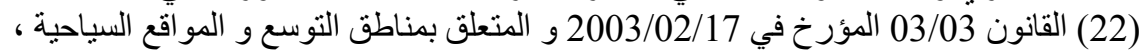

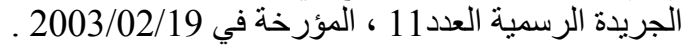

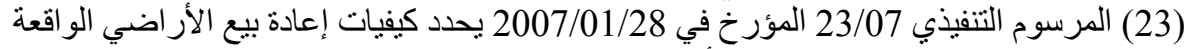

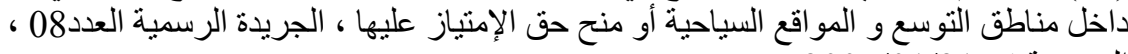

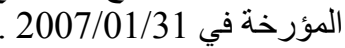

(24) القانون 08/02 المؤرخ في 2002/05/08 يتعلق بشروط إنشاء الددن الجديدة و تهيئتها ، الجريدة

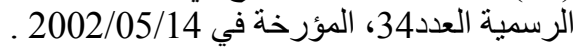

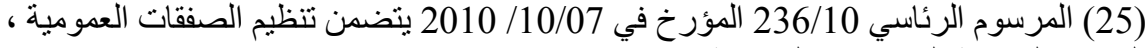

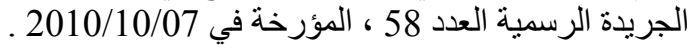

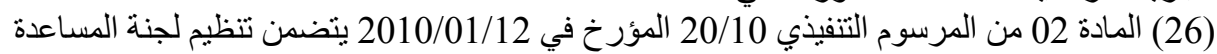

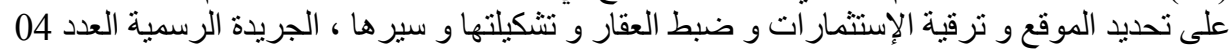

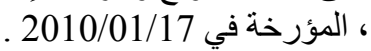

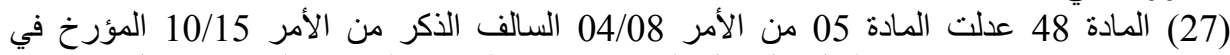

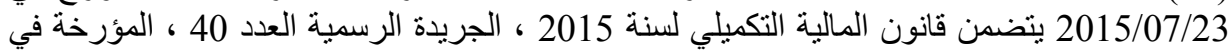
2015/07/23

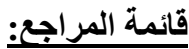

الرسرسوم الرئاسي 236/10 المؤرخ في 2010/10/07 يتضمن تنظيم الصفقات العمومية ، الجريدة

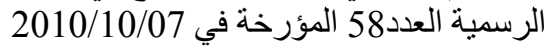

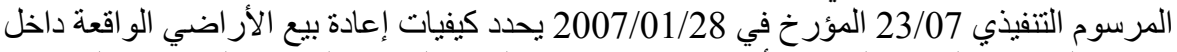

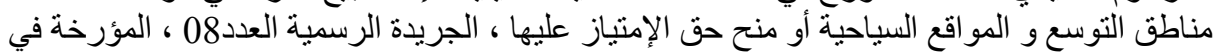
2007/01/31 
المرسوم التنفيذي 119/07 المؤرخ في 2007/04/23 يتضمن إنثاء الوكالة الوطنية للوساطة و الضبط

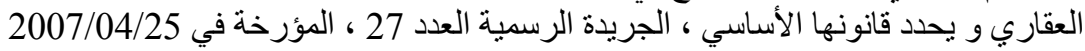

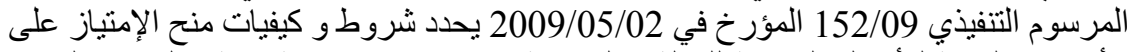

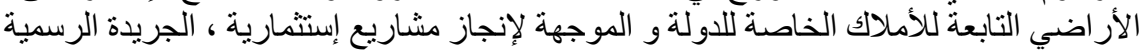

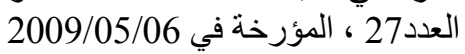

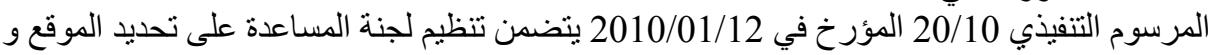
ترقية الإستثمار ات و ضبط العقار و تثنكيلتهاو سير ها ، الجريدة الرسمية العدد04 ، المؤرخة في 2010/01/17 الأبحاث الجامعية و المقالات : الإنية

أسماء منصور ، عقد الإمتياز كوسيلة لإستغلال العقار الصناعي ، رسالة ماجستير ، كلية الحقوق ،

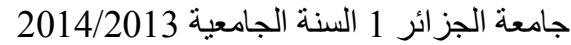

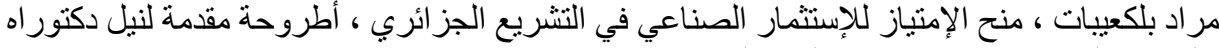

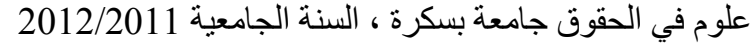

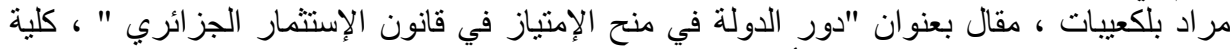

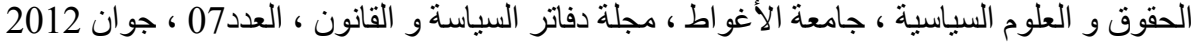

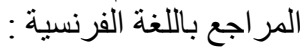

Examen de la politique de l'investissement, ALGERIE, conférence des nations unie sur le commerce et le développement Manuel de droit domanial, ministère des finances, direction générale des domaines nationaux, unité central de formation, septembre 2007

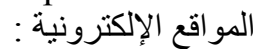
منتديات الحقوق و العلوم القانونية ، عنوان المقال "العقار الصناعي في الجزائر " : www.droit .dz. com www.joradp.dz: الجريدة الرسمية الجزائرية 